(C) 2018 by the Arizona Board of Regents on behalf of the University of Arizona. The online version of this article is published within an Open Access environment subject to the conditions of the Creative Commons Attribution-NonCommercial-ShareAlike licence <http://creativecommons.org/licenses/by-nc-sa/4.0/> . The written permission of Cambridge University Press must be obtained for commercial re-use.

\title{
THE VALLEY OF JUIGALPA, MAYALES RIVER SUBBASIN MICROREGION (CHONTALES, NICARAGUA) DATE LIST I
}

\author{
Natalia R Donner ${ }^{1 *} \cdot$ Alexander Geurds $^{1,2}$ \\ ${ }^{1}$ Faculty of Archaeology, Leiden University, Einsteinweg 2, Leiden 2333 CC, The Netherlands. \\ ${ }^{2}$ School of Archaeology, University of Oxford, 36 Beaumont St., Oxford OX1 2PG, United Kingdom.
}

\begin{abstract}
The chronology of human presence in Chontales, central Nicaragua, was established by Franck Gorin (1989), who applied a combination of absolute dates and ceramic associations to build a sequence comprised of six different phases. However, interpretative and chronological issues have arisen due to two main problems. First, the sequence was based on stylistic associations to polychrome ceramics from Pacific Nicaragua. Second, the sample analyzed by Gorin shows contextual bias and lacks sufficient absolute dates. As a result, a comprehensive regional research plan was established to test the current accepted chronology, and redefine it where necessary. In this paper, we present the first date list for the Valley of Juigalpa, Mayales River subbasin (Chontales, Nicaragua). Contrary to Gorin's proposal, which established a chronology from 500 BC through AD 1600, reports on new seventeen radiocarbon $\left({ }^{14} \mathrm{C}\right)$ assays show a cultural sequence from $1420 \pm 30 \mathrm{BP}$, or cal AD 595-660 $( \pm 2 \sigma)$ through the present.
\end{abstract}

KEYWORDS: bulk organic sediment dating, Chontales, lower Central America, Nicaragua, radiocarbon dating.

\section{INTRODUCTION}

The Valley of Juigalpa is located $25 \mathrm{~km}$ northeast of Lake Cocibolca, the largest freshwater lake in Central America (Montenegro-Guillén 2003), which strategically connects the Pacific coastal region of Rivas to the Caribbean Sea through the San Juan River (Huete-Pérez et al. 2013) (Figure 1). The Mayales River runs through the aforementioned valley, originating in the Amerrisque Mountains, which are part of the Central American Range. The river irrigates the valley before discharging into the lake. Human presence during the later pre-Hispanic period and early colonial times (500 BC through AD 1600) was documented by Franck Gorin (1989), who established a ceramic sequence for the region. Gorin dated a total of nine charcoal samples from three different archaeological sites, of which only five were considered for his proposal. The sequence represents a rigorous attempt to determine the history of human occupation in Chontales, but it is problematic due to three principal reasons. First, more than 100 sites were dated based on only five radiocarbon $\left({ }^{14} \mathrm{C}\right)$ dates from a total of eight stratigraphic excavation units at merely four sites. Second, a questionable analytical methodology was chosen, as part of which the non-decorated sherds $(85 \%)$ were not considered in the analysis. Third, ethnohistorical deductions, lacking empirical basis, co-determined the sequence dates. The ceramic chronology was mainly supported through connections with polychrome pottery from the Greater Nicoya region, the cultural subarea identified along parts of the Pacific coast, which represents less than $5 \%$ of the ceramic assemblages in Chontales. This proposed chronology is comprised of six phases: Mayales I (500-200 BC), Mayales II (200 BC-AD 400), Cuisalá (AD 400-800), Potrero (AD 800-1200), Monota (AD 1200-1500), and Cuapa (AD 14001600). However, the earliest absolute date reported was Gif-6893:1510 \pm 60 BP. Consequently, a more comprehensive chronological approach was necessary.

The Proyecto Arqueológico Centro de Nicaragua (PACEN), under the direction of Dr. Alexander Geurds (Leiden University and University of Oxford), started a systematic research program in the Valley of Juigalpa in 2007 with four main objectives. The first goal

\footnotetext{
*Corresponding author. Email: n.r.donner@arch.leidenuniv.nl.
} 


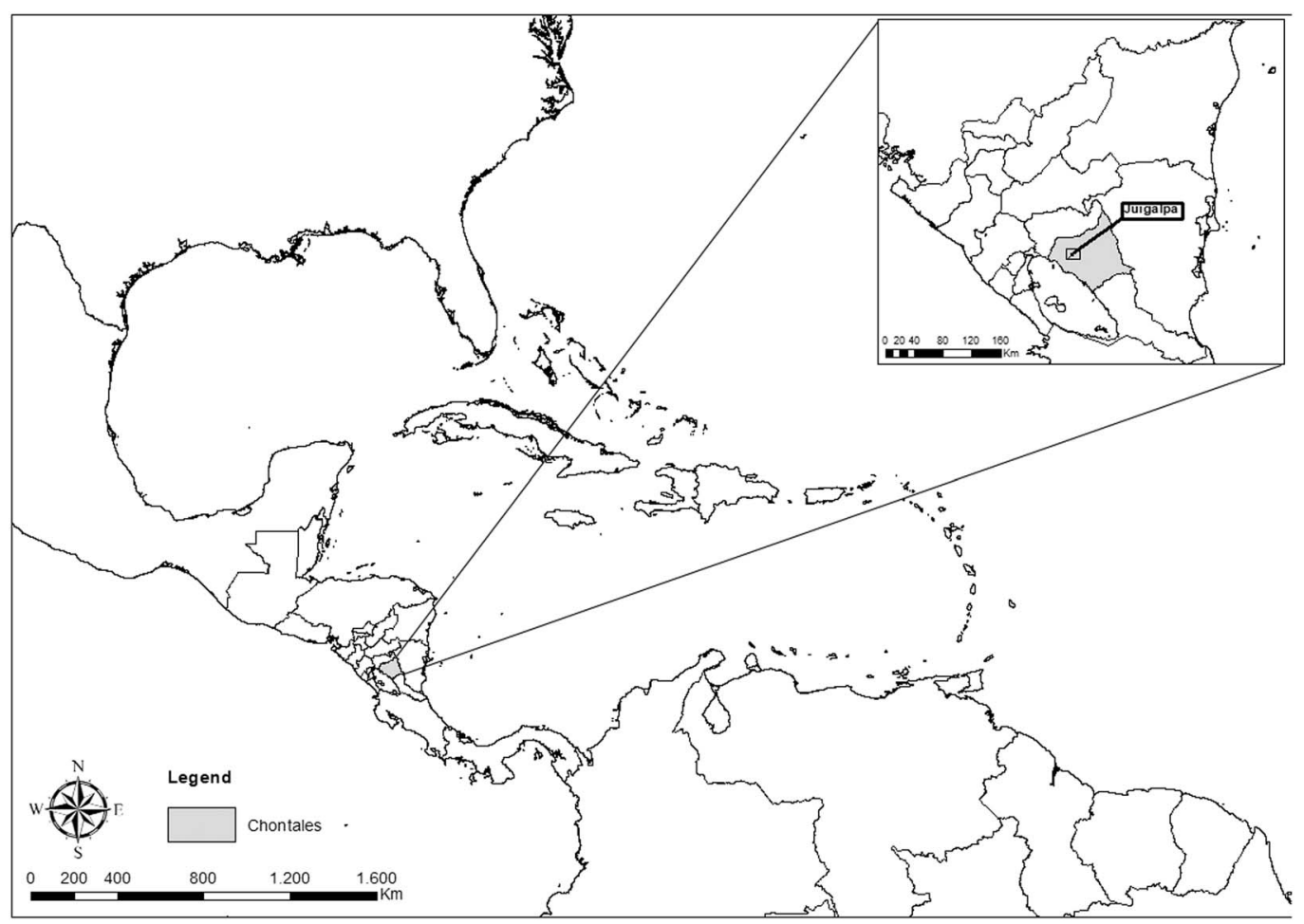

Figure 1 Map showing the study region in its context, northeast of Lake Cocibolca, in the Department of Chontales, Nicaragua.

consisted of mapping the site of Aguas Buenas, which features 371 man-made mounds built to form a geometric design (Geurds and Terpstra 2017). Second, selected man-made mounds were excavated to establish their functionality in relationship to their morphology and location within the site. Additionally, petroglyphs within the site were documented (Vlaskamp et al. 2014). Preliminary results suggested that, in order to understand Aguas Buenas' role in pre-Hispanic Chontales, a more regional approach was necessary. Therefore, since 2014, a systematic high-intensity full-coverage surface survey was conducted in a $52-\mathrm{km}^{2}$ area, alongside the excavation of several mounded sites, in order to redefine the chronology of human presence in the valley. This study represents the most exhaustive regional approach to the history of human occupation in the Mayales River subbasin.

\section{THE NEW DATES}

Seventeen samples were recovered through archaeological excavations at eight different sites and were submitted to obtain new accelerator mass spectrometry (AMS) ${ }^{14} \mathrm{C}$ ages (see Figure 2). Seven samples correspond to carbonaceous charred material, while 10 consist of organic bulk sediment. Charred materials were collected during the excavations and selected for their key cultural stratigraphic contexts. Samples were wrapped in aluminum foil, labeled and sealed in plastic bags. Once in the lab, pretreatment consisted of an acid/alkali/acid wash for the removal of carbonate and soluble humic acids. Initially, an acidic solution was applied $(10 \% \mathrm{HCl})$ to cause a carbonate reaction. Then, it was tested again after $30 \mathrm{~min}$, and when no further reaction was observed, it was rinsed neutral. Subsequently, the sample was soaked twice in an alkali $(2 \%$ 


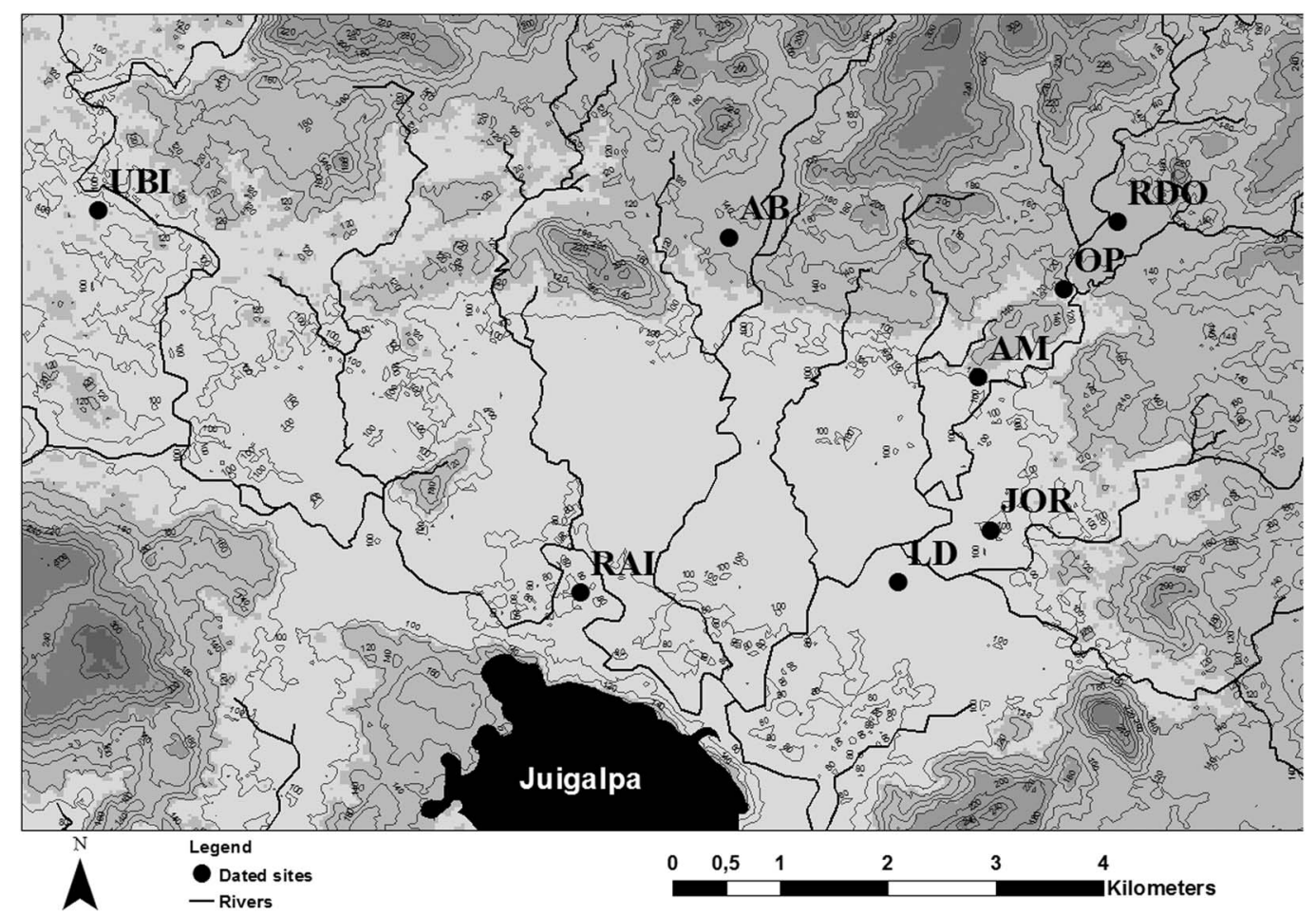

Figure 2 Map of the Valley of Juigalpa showing the archaeological sites mentioned in text.

$\mathrm{NaOH}$ ), the first time for $2 \mathrm{hr}$ and then a second application for $1 \mathrm{hr}$. Afterwards, it was rinsed neutral. Finally, another acidic solution $(10 \% \mathrm{HCl})$ was applied for $30 \mathrm{~min}$, then the charcoal was rinsed neutral with deionized water. Once neutral, the charcoal was dried in an oven at $90^{\circ} \mathrm{C}$.

Bulk organic sediment samples were taken using an adapted version of the technique applied for luminescence dating (Nelson et al. 2015), with some modifications suggested by Pagán Jiménez (personal communication 2016) and adaptations performed in the field. First, the stratigraphy of the profile was analyzed, and specific spots were selected for sampling, subsequently recorded using a Total Station. The area was cleared with equipment, previously sterilized with distilled water. Then, 3-inch-wide by 5.9-inch-long (approximately $7.6 \times 15 \mathrm{~cm}$ ) labeled PVC tubes and lids were also surface sterilized with distilled water immediately before sampling. Afterwards, the tube was perpendicularly inserted into the profile using a rubber mallet. When the necessary amount of sediment was retrieved (100-1000 mg, depending on the hardness of the soil), the tube was closed with the second lid, wrapped in aluminum tape, sealed in a plastic bag, and kept in the shade until it was possible to store it in a refrigerator. Later, at the lab, pretreatment for dating first involved soaking the sediment in warm deionized water for $1-3 \mathrm{hr}$ to soften the particles for a more effective sieving process, which was then performed with a 180 micron sieve. Afterward, materials were processed with $10 \% \mathrm{HCl}$, in two different applications for $30 \mathrm{~min}$ each and then dried in an oven at $90^{\circ} \mathrm{C}$ to remove all carbonates. The results are presented in Table 1. Information on the sites is yet unpublished, but some can be found in Magnus (1975a, 1975b), Gerstle (1976), Gorin (1989), Lange et al. (1992), as well as Geurds and Van Broekhoven (2009, 2011), Geurds et al. (2010), Geurds (2013), Vlaskamp et al. (2014), and Arteaga Saucedo (2017). 
Table 1 Radiocarbon dates for the Valley of Juigalpa (Mayales river subbasin, Chontales, Nicaragua), cal BP dates calibrated with IntCal13 using the high probability density range method (HPD) (Bronk Ramsey 2009; Reimer et al. 2013).

\begin{tabular}{|c|c|c|c|c|c|c|c|c|c|c|c|}
\hline Beta nr & Site & Unit & Level & $\begin{array}{l}\text { Stratigraphic } \\
\text { unit }\end{array}$ & Material & Pretreatment & $\begin{array}{l}{ }^{14} \mathrm{C} \text { dates } \\
\mathrm{BP}( \pm 1 \sigma)\end{array}$ & $\mathrm{Cal} \mathrm{BC} / \mathrm{AD}( \pm 2 \sigma)$ & $\begin{array}{l}\delta^{13} \mathrm{C} \\
(\% o)\end{array}$ & Phase & $\begin{array}{l}\text { In Gorin's } \\
\text { chronology } \\
(1989)\end{array}$ \\
\hline 457282 & Aguas Buenas & M177 & N/A & N/A & Organic sediment & Acid washes & $1420 \pm 30$ & $\begin{array}{l}\text { Cal AD 595-660 } \\
\text { (cal BP 1355-1290) }\end{array}$ & -17.9 & Cuisalá & $\begin{array}{l}\text { Cuisalá?, } \\
\text { Potrero? \& } \\
\text { Monotá }\end{array}$ \\
\hline 443735 & Aguas Buenas & 1 & 3 & II & Charred material & Acid/alkali/acid & $4780 \pm 30$ & $\begin{array}{l}\text { Cal BC 3641-3519 } \\
\text { (cal BP 5590-5468) }\end{array}$ & -27.2 & $\begin{array}{l}\text { Pre- } \\
\text { Ceramic }\end{array}$ & $\begin{array}{l}\text { Cuisalá?, } \\
\text { Potrero? \& } \\
\text { Monotá }\end{array}$ \\
\hline 457266 & Alcides Montiel & 1 & 7 & VII & Charred material & Acid/alkali/acid & $1260 \pm 30$ & $\begin{array}{l}\text { Cal AD } 670-775 \text { (cal BP } \\
1280-1175) \text { and cal AD } \\
790-800(\mathrm{cal} \text { BP } \\
1160-1150)\end{array}$ & -25.4 & Cuisalá & NA \\
\hline 457280 & Oporta & $1 \mathrm{~B}$ & 5 & $\begin{array}{l}\text { XIX, XX, } \\
\text { VIIM, XXI }\end{array}$ & Organic sediment & Acid washes & $920 \pm 30$ & $\begin{array}{l}\text { Cal AD 1025-1190 } \\
\text { (cal BP 925-760) }\end{array}$ & -18.5 & Potrero & NA \\
\hline 457274 & Oporta & $1 \mathrm{~A}$ & 5 & $\mathrm{X}$ & Charred material & Acid/alkali/acid & $940 \pm 30$ & $\begin{array}{l}\text { Cal AD 1020-1165 } \\
\text { (cal BP 930-785) }\end{array}$ & -25.7 & Potrero & NA \\
\hline 443733 & $\begin{array}{l}\text { Rosa Dolores } \\
\text { Oporta }\end{array}$ & 2 & & IIIA & Organic sediment & Acid washes & $570 \pm 30$ & $\begin{array}{l}\text { Cal AD } 1305-1365 \text { (cal BP } \\
645-585 \text { ) and cal AD 1385- } \\
1420 \text { (cal BP 565-530) }\end{array}$ & -12.8 & Monota & NA \\
\hline 457277 & $\begin{array}{l}\text { Rosa Dolores } \\
\text { Oporta }\end{array}$ & $1 \mathrm{~B}$ & 3 & $\mathrm{X}$ & Charred material & Acid/alkali/acid & $210 \pm 30$ & $\begin{array}{l}\text { Cal AD 1645-1685 (cal BP } \\
305-265 \text { ) and cal AD } 1735- \\
1805 \text { (cal BP 215-145) and } \\
\text { cal AD 1930-post } 1950 \text { (cal } \\
\text { BP 20-post } 0 \text { ) }\end{array}$ & -25.6 & Cuapa & NA \\
\hline 457268 & $\begin{array}{l}\text { Rosa Dolores } \\
\text { Oporta }\end{array}$ & $1 \mathrm{~B}$ & 4 & XVII & Charred material & Acid/alkali/acid & $110 \pm 30$ & $\begin{array}{l}\text { Cal AD } 1680-1765 \text { (cal BP } \\
270-185 \text { ) and cal AD } 1800- \\
1940(\text { cal BP } 150-10) \text { and } \\
\text { post AD } 1950 \text { (post BP 0) }\end{array}$ & -24.8 & Cuapa & NA \\
\hline 457281 & Roberto Amador & RAI25 & N/A & N/A & Organic sediment & Acid washes & $1010 \pm 30$ & $\begin{array}{l}\text { Cal AD 985-1040 (cal BP } \\
965-910 \text { ) and cal AD 1110- } \\
1115 \text { (cal BP 840-835) }\end{array}$ & -18.5 & Potrero & NA \\
\hline 457270 & Roberto Amador & 1 & 5 & VII & Charred material & Acid/alkali/acid & $1020 \pm 30$ & $\begin{array}{l}\text { Cal AD 980-1035 } \\
\text { (cal BP 970-915) }\end{array}$ & -25.3 & Potrero & NA \\
\hline 457276 & Barillas & 3 & 14 & $\mathrm{X}$ & Organic sediment & Acid washes & $730 \pm 30$ & $\begin{array}{l}\text { Cal AD 1255-1290 } \\
\text { (cal BP 695-660) }\end{array}$ & -13.6 & Monota & Cuapa \\
\hline
\end{tabular}




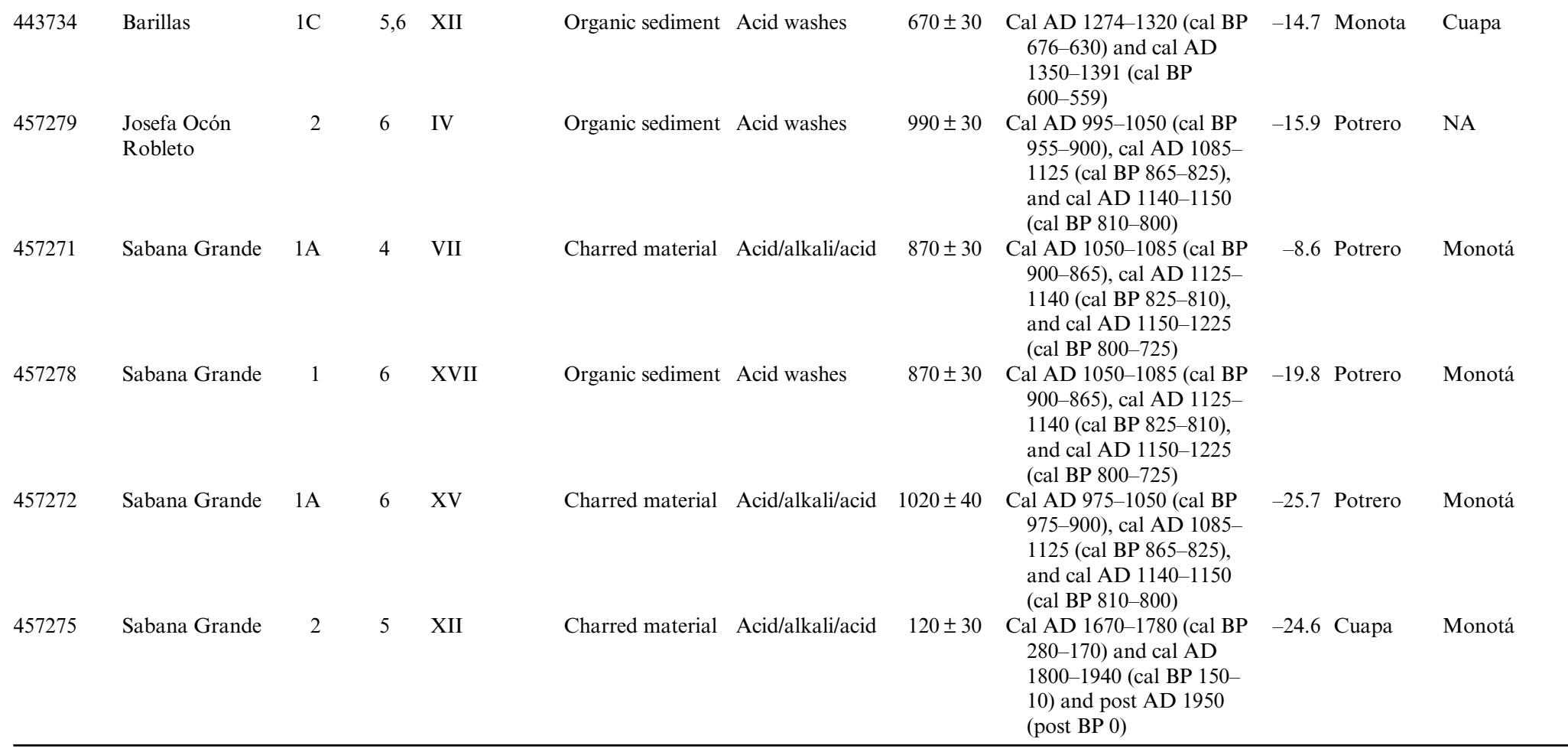


Two different samples were taken at the archaeological site of Aguas Buenas (AB). Sample Beta-457282 was collected from Mound 177 (M177), by taking advantage of a road cut into the mound. The structure is located in the southwest part of the site, specifically on the second arc of mounds counting from outside to inside, that conform the elliptical design of the site. This sample was taken after clearing the profile and reaching an archaeological layer within the mound, which was delimited by a line of stones both on top and at the bottom. This layer yielded ceramics as well as chipped stone fragments. With this date, we have established the construction event of that portion of the site to have taken place around $1420 \pm 30 \mathrm{BP}$, or cal AD 595-660 $( \pm 2 \sigma)$. The second sample, Beta-443735, corresponds to an archaeological $2 \times 2 \mathrm{~m}$ stratigraphic excavation, where the sample was retrieved in the cultural stratigraphic unit SII, Level 3 (21-30 cm below ground surface). This cultural layer yielded $71 \%$ of all archaeological materials from the unit, which consisted of ceramic, chipped stone, and burnt clay fragments. This context belongs to a section of the site that was possibly used a few centuries after the construction of the mounds that feature the geometric design (Gorin 1989). However, the charred materials yielded a $4780 \pm 30 \mathrm{BP}$, or cal BC 3641 to $3519( \pm 2 \sigma)$ date, which correspond with the pre-ceramic age in the region of study. Also, the materials associated to this cultural layer are stylistically consistent with the Cuapa phase (Gorin 1989:668-70). Therefore, we think this date corresponds to contamination caused by erosion, which exposed an older arboreal species that preceded human occupation $\left(\delta^{13} \mathrm{C} \%=-27.2\right)$. The stratigraphy of the area of study is very shallow, therefore a few centimeters could potentially represent thousands of years.

Sample Beta-457266 was obtained from the site Alcides Montiel (AM), located $2.5 \mathrm{~km}$ southeast of Aguas Buenas and featuring 13 man-made mounds. Excavation unit 1 (AMEU1) consisted of a $1 \times 1 \mathrm{~m}$ pit that was placed on Mound 7 (AM7), also affected by the construction of a road. The profile made by a bulldozer was cleaned and stratigraphically excavated, to study mound construction materials and techniques. The sample for dating was retrieved, together with five ceramic fragments, below a stone floor that was part of the mound, $70 \mathrm{~cm}$ below ground surface.

Another group of dates was recovered from sites located along the Carca river, at the eastern portion of the research area. Beta-457280 was collected at the archaeological site Oporta (OP), located west of the river and being comprised of 33 man-made mounds. Excavation unit 1 (OPEU1) consisted of a $2 \times 1 \mathrm{~m}$ stratigraphic excavation placed at the west foot of Mound 15 (OP15). The cultural stratigraphic units sampled at $50 \mathrm{~cm}$ below ground surface level were interpreted as mound leveling and filling layers, which all yielded ceramic, chipped stone, and burnt clay fragments. Hence, this context establishes the event of the construction of the mound. For comparative purposes, sample Beta-457274 was taken from the same excavation unit (OPEU1) and arbitrary level (50 cm below ground surface), but from the the off-mound sector, stratigraphic unit SX. This cultural layer yielded ceramic, burnt clay, and chipped stone fragments, as well as ground stone artifacts. These archaeological materials reflect practices associated to the domestic activities performed on the mound. Results indicate a twenty year difference between the sediment used as filling and the off-mound layer. However, stratigraphic unit SX continues until Level 7 (70 $\mathrm{cm}$ below ground surface level), making it probable that the use of the mound and the activities around it commenced right after its construction.

The second site sampled along the Carca river is Rosa Dolores Oporta (RDO), located east of the river and is comprised of 27 man-made mounds. Sample Beta-443733 was collected from a $2 \times 2 \mathrm{~m}$ stratigraphic excavation situated in a flat area surrounded by three large mounds ( $15 \mathrm{~m}$ diameter on average, two measure $50 \mathrm{~cm}$ in height and the biggest one $1.30 \mathrm{~m})$. 
The dating sample was associated to a complete ceramic vessel, found after $20 \mathrm{~cm}$ of archaeological sterile layers. This vessel is believed to have been purposely placed before the construction of mounds that would define the plaza. There were no other finds related to this feature.

Samples Beta-457277 and Beta-457268, on the other hand, were both recovered from a $2 \times 1 \mathrm{~m}$ stratigraphic excavation. The first sample was collected $30 \mathrm{~cm}$ below the ground surface, in an off-mound layer with ceramic fragments and abundant charred material, suggestive of intentional burning or contamination due to subsequent slash-and-burn agricultural practices. The second sample was recovered $40 \mathrm{~cm}$ below ground surface, in a layer right beneath the mound, which yielded chipped stone and ceramic fragments. The date obtained through AMS also indicates a contaminated deposit.

The next two samples were collected at a site named Roberto Amador (RAI), which is comprised of 25 man-made mounds placed on a meander at the Mayales river. Sample Beta-457281 was taken in Mound 25 (RAI25), within a cultural layer that had been previously exposed due to the construction of a nearby house. Sample Beta-457270, on the other hand, was collected from a $1 \times 1 \mathrm{~m}$ stratigraphic excavation, $50 \mathrm{~cm}$ below ground surface level and within Layer SV, where ceramic, charcoal, chipped stone, and animal bone fragments were also documented.

According to Magnus (1975a, 1975b) and Gorin (1989), the site of Barillas (UBI) developed during the Cuapa phase (AD 1400-1600). However, samples Beta-457276 and Beta-443734 indicate a slightly earlier chronology, which could be explained as a bias related to the different methodologies to select excavation loci within the site, and do not necessarily rule out a later continuation of the settlement. Beta- 457276 was collected $50 \mathrm{~cm}$ below ground surface level, in an off-mound $3 \times 1 \mathrm{~m}$ stratigraphic excavation placed at the foot of Mound 27 (UBI27). The context in which the sample was retrieved corresponds to the original floor level, right next to the foundation of the mound. It follows that the radiocarbon dates should reflect mound-related practices. Sample Beta-443734, on the other hand, was taken $55 \mathrm{~cm}$ below ground surface level, from a cultural layer at the base of Mound 61 (UBI61). Alongside yielding ceramic fragments, this stratigraphic unit also represents the architectural foundation of the mound, with stones forming the structures' outer wall being placed immediately on top of it.

Along the Carca river, at the southeast of the research area, eight mound clusters were recorded during the surveys. Two of these mounded sites were excavated in order to understand synchronic and diachronic material culture variability. Beta-457279 was collected at the Josefa Ocón Robleto site (JOR), at $60 \mathrm{~cm}$ below ground surface in a $2 \times 2 \mathrm{~m}$ stratigraphic excavation, between two mounds. The layer was interpreted as cultural, because it contained ceramic, chipped stone, burnt clay, and charcoal fragments; and possibly corresponded to a hearth. Four additional samples were retrieved from the site Sabana Grande (LD), previously excavated by Richard Magnus in the 1970s. Magnus placed the occupation of the site between AD 800 and 1550. Sample Beta- 457271 was collected at $40 \mathrm{~cm}$ below ground surface in a $1.5 \times 1 \mathrm{~m}$ stratigraphic excavation, located next to a man-made mound (GS2). The cultural layer started with horizontal ceramic fragments, and also contained chipped stone. Sample Beta-457278 was collected in the same stratigraphic excavation, but $51-60 \mathrm{~cm}$ below ground surface, in a layer that also contained ceramic, chipped stone, charcoal, and animal bone fragments (SXVII). The similarities between the two layers might suggest that they correspond to a possible refuse area located next to the mound, which possibly reflect daily practices. Beta-457272 was also collected $51-60 \mathrm{~cm}$ below ground surface, in Layer SXV, located on top of Layer SXVII, where the 
previous sample was retrieved. In spite of the stratigraphic position, Beta-457272 yielded an older date than Beta-457278. However, the discrepancy between stratigraphic position and radiocarbon age could be explained by the two different materials dated. Beta-457278, stratigraphically older but yielding cal AD $870 \pm 30 \mathrm{BP}$, or cal AD 1050-1085 ( $\pm 2 \sigma)$, consisted of organic sediment. In contrast, Beta-457272, stratigraphically younger, obtained a $870 \pm 30 \mathrm{BP}$, or cal AD 975-1050 $( \pm 2 \sigma)$ and corresponded to charred material $\left(\delta^{13} \mathrm{C}=-25.7\right)$. Finally, Beta-457275, was also recovered at Sabana Grande, but from a $2 \times 2 \mathrm{~m}$ stratigraphic excavation on a flat area surrounded by mounds. The context corresponds to a cultural layer, which contained ceramic, chipped stone, ground stone, animal bone, and charcoal fragments. However, the ${ }^{14} \mathrm{C}$ age obtained suggests contamination.

\section{CONCLUSION}

We suggest a reassessment of the chronology for the Valley of Juigalpa. Results so far indicate three main periods of human occupation. The first one spans from $1420 \pm 30 \mathrm{BP}$, or cal AD $595-660( \pm 2 \sigma)$ to $1260 \pm 30 \mathrm{BP}$, or cal AD 670-775 $( \pm 2 \sigma)$, and includes two completely different sites: Aguas Buenas, interpreted as a gathering place for communities throughout and possibly beyond the research area, as well as Alcides Montiel, a site comprised of 21 mounds possibly used for habitation and domestic practices.

The second period seems to represent a denser occupation of the valley, and is defined by four different sites varying in size from 23 to 80 mounds (i.e., Roberto Amador, Josefa Ocón Robleto, Oporta, and Sabana Grande), spanning from $1020 \pm 30$ BP, or cal AD 980-1035 ( $\pm 2 \sigma)$ to $870 \pm 30 \mathrm{BP}$, or cal AD $1050-1085( \pm 2 \sigma)$. In comparison to the previous moment, all sites feature traces of daily practices, and yielded higher densities of material culture remains, both at the surface and in stratigraphy. Except for Josefa Ocón Robleto, the sites also feature polychrome pottery fragments and obsidian, suggesting participation in networks of interaction with the Pacific coast and northern Nicaragua.

The third period is represented by two different sites, Barillas and Rosa Dolores Oporta, which dated from $730 \pm 30 \mathrm{BP}$, or cal AD 1255-1290 $( \pm 2 \sigma)$ to $570 \pm 30 \mathrm{BP}$, or cal AD 1305-1365 $( \pm 2 \sigma)$. These two sites differ markedly in size, with Barillas featuring 129 mounds, while Rosa Dolores Oporta counts 28 mounds. In spite of this discrepancy, the excavation contexts suggest daily practices, as well as formalized communal open spaces or plazas, surrounded by man-made mounds. No polychrome sherds were retrieved in any of these sites; however, a very small fragment of obsidian was found in Rosa Dolores Oporta. This absence of Greater Nicoya ceramics at both sites, combined with the minimal presence of obsidian, indicates a change in the networks of interaction that were observed during the previous period.

Upon comparison of our ${ }^{14} \mathrm{C}$ dating results to Gorin's chronology, we conclude that there is currently no material evidence to support human presence in the research area before $1420 \pm 30 \mathrm{BP}$, or cal AD 595-660 $( \pm 2 \sigma)^{1}$. Apart from that, there seems to be an apparent gap between cal AD 670-775 and 980-1035, which could be explained by the limitations of the dated sample. However, it is relevant to mention two aspects regarding this gap. First, Gorin identified a stratigraphic interval in the occupation of La Pachona, a site located $2 \mathrm{~km}$ south of Juigalpa, but he placed it between AD 400 and 1200. Second, the author only retrieved two absolute dates for this conflictive period. The first one, Gif-7227:430 $\pm 60 \mathrm{BP}$ was interpreted as a contamination, while the second one, Gif-6894:1160 $\pm 60 \mathrm{BP}$, or cal AD 810-955, could in fact correspond

\footnotetext{
${ }^{1}$ Gorin's earliest sample dated $1510 \pm 60 \mathrm{BP}$, or cal AD 470-605.
} 
to the second phase identified by us. The discrepancy could be explained by the refinement in dating techniques achieved over the past few decades. Further ${ }^{14} \mathrm{C}$ results will clarify whether this interval meant a lack of human settlements in the valley or rather a sampling bias. Apart from that, the Cuapa phase, which has been already questioned (Geurds 2013), remains elusive in the dated sample.

This paper intends to present the first in a series of dating lists for the Valley of Juigalpa. Samples recovered at other excavated sites within the research area will shed light on its pre-Hispanic and early colonial history.

\section{ACKNOWLEDGMENTS}

We gratefully acknowledge the help of Simone Casale, who designed the maps for this contribution. We would also like to thank Alejandro Arteaga Saucedo, Rodrigo Ángeles Flores, Kaz van Dijk, Irene Torregiani, Arnau Llaudet, Waka Kuboyama, Pol Miguel Sallés, Nagore Sánchez García, Iris van den Brink, Lucy Gill, Matt Abtosway, Tomás Viva, Sairín Duarte, and Eleucterio Castillo for their collaboration in the excavations and their help for taking the samples in the field. Also, we express our gratitude to the Nicaraguan Institute of Culture, and in particular its co-director Luis Morales Alonso and the director of the Archaeology Directorate, Ivonne del Carmen Miranda Tapia, for their continued support of the project and issuing the permits to export samples. We are also indebted to the staff of the Beta Analytic Laboratory for running the dates. This research was made possible by the VIDI grant (PI A. Geurds) "Networked practices of contact: Cultural identity at the Late Prehistoric settlement of Aguas Buenas, Nicaragua, AD 500-1522", of the Netherlands Organisation for Scientific Research (NWO).

\section{REFERENCES}

Arteaga Saucedo A. 2017. Reconstrucción del paisaje social prehispánico en la microcuenca del río Mayales, Chontales, Nicaragua [unpublished MA thesis]. Mexico City: Universidad Nacional Autónoma de México.

Bronk Ramsey C. 2009. Bayesian analysis of radiocarbon dates. Radiocarbon 51(1):337-60.

Gerstle A. 1976. Analysis of Lithic Artefacts from Sabana Grande [unpublished MA thesis]. Boulder: University of Colorado.

Geurds A. 2013. The Cuapa complex: a note on the last pre-Hispanic period from Central Nicaragua. Mexicon: Zeitschrift für Mesoamerikaforschung 35(6):148-51.

Geurds A, Terpstra D. 2017. Circular reasoning in mound building?Large- scale planned construction patterns at the Aguas Buenas site (A.D. 4001525). In: Adam K. Benfer, editors. War \& Peace: Conflict and Resolution in Archaeology. Proceedings of the 45th Annual Chacmool Archaeology Conference. University of Calgary, Alberta: Chacmool Archaeological Association. p 47-59.

Geurds A, Van Broekhoven LNK. 2009. La historia y el patrimonio en el departamento de Chontales. Resultados de la primera temporada del Proyecto Arqueológico Chontales. Mi Museo y Vos 3(8):4-7.

Geurds A, Van Broekhoven LNK. 2011. Chontales en su sentido étnico. Mi Museo y Vos 5:6-10.
Geurds A, Zambrana J, Villanueva C. 2010. Escultura de piedra en el Centro de Nicaragua: logros y desafíos. Mi Museo y Vos 4(13):4-7.

Gorin F. 1989. Archaeologie de Chontales, Nicaragua. Volume 1 [unpublished $\mathrm{PhD}$ dissertation]. Université de Paris I (Panthéon-Sorbonne).

Huete-Perez JA, Tundisi JG, Alvarez PJ. 2013. Will Nicaragua's interoceanic canal result in an environmental catastrophe for Central America. Environmental Science and Technology 47(23): 13217-19.

Lange F, Sheets P, Martínez A, Abel-Vidor S. 1992. The Archaeology of Pacific Nicaragua. Albuquerque: University of New Mexico Press.

Magnus R. 1975a. Present Archaeological Research in Chontales, Nicaragua: Its Implications for the Prehistory of Central America (report). Managua, Nicaragua: Banco Central de Nicaragua.

Magnus R. 1975b. La secuencia de la costa Atlántica y zona central de Nicaragua. Boletín Nicaragüense de Bibliografía y Documentación 16. Managua, Nicaragua: Banco Central de Nicaragua.

Montenegro-Guillén S. 2003. Lake CocibolcalNicaragua: Lake Basin Management Initiative Experience and Lessons Learned. Brief, USAID. Washington, DC: World Bank. 12 p.

Nelson MS, Gray HJ, Johnson JA, Rittenour TM, Feathers JK, Mahan SA. 2015. User guide for luminescence sampling in archaeological and 
geological contexts. Advances in Archaeological Practice 3(2):166-77.

Reimer PJ, Bard E, Bayliss A, Beck JW, Blackwell PG, Bronk Ramsey C, Buck C, Cheng H, Edwards RL, Friedrich M, Grootes PM, Guilderson TP, Haflidason H, Hajdas I, Hatté C, Heaton TJ, Hoffmann DL, Hogg AG, Hughen KA, Kaiser KF, Kromer B, Manning SW, Niu M, Reimer RW, Richards DA, Scott
EM, Southon JR, Staff RA, Turney CSM, van der Plicht J. 2013. IntCal13 and Marine13 radiocarbon age calibration curves $0-50,000$ years cal BP. Radiocarbon 55(4):1869-87.

Vlaskamp RJC, Geurds A, Jansen R. 2014. Reporte de las investigaciones arqueológicas entre 20112014 en el sitio prehispánico de Aguas Buenas, Chontales, Nicaragua. Mi Museo y Vos 8(29): $6-12$. 